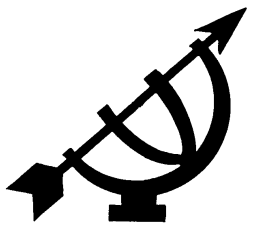

\section{The role of values in school discipline}

Jeannette de Klerk

Faculty of Education

University of Stellenbosch

STELLENBOSCH

E-mail: jdkl@sun.ac.za

\author{
Julialet Rens \\ Faculty of Educational Sciences \\ Potchefstroom University for CHE \\ POTCHEFSTROOM \\ soojar@puknet.puk.ac.za
}

\begin{abstract}
The role of values in school discipline

Despite the fact that the Constitution of South Africa uses language that could be described as "value-language", our country is experiencing an intense moral crisis. There is an urgent need to establish ways of finding answers to the value crisis in South Africa. Morality has been and is part of education. In this article the relationship between values, education and discipline is addressed from a Biblically-based (in this case, reformational) perspective. The teacher as secondary educator plays an important role in the establishment of values among learners. The Department of Education has made clear its intention to establish values in schools in its Manifesto on Values, Education and Democracy. The values emphasised in this document concur with the ideals of nation-building in the new democratic South Africa. Unfortunately, the absence of discipline and self-discipline among learners and educators implies that these ideals cannot be realised. The main cause of discipline problems can possibly be ascribed to the absence of a value system rooted in a specific life and worldview, for without such a perspective the management of discipline problems can only be symptomatic.
\end{abstract}

\section{Opsomming}

Die rol van waardes in dissipline in skole

Nieteenstaande die feit dat die Grondwet van Suid-Afrika taal gebruik wat as "waarde-taal" beskryf kan word, ondervind ons land 'n intense morele krisis. Daar is 'n dringende behoefte om antwoorde op die waardekrisis in ons land te vind. Moraliteit is en was altyd 'n deel van opvoeding. In hierdie artikel word die verhouding tussen waardes, opvoeding en dissipline vanuit 'n Bybelse (in hierdie geval: reformatoriese) denkraamwerk ondersoek. Die onderwyser as sekondêre opvoeder speel ' $n$ belangrike rol in die vestiging van waardes by leerders. Die Departement van Onderwys het sy voorneme om waar- 
des in skole te vestig duidelik gemaak in sy publikasie Manifesto on Values, Education and Democracy. Die waardes wat in hierdie dokument beklemtoon word, stem ooreen met die gedagte van nasiebou in die nuwe demokratiese Suid-Afrika. Ongelukkig veroorsaak die afwesigheid van dissipline en selfdissipline onder leerders en onderwysers dat hierdie ideale nie bereik kan word nie. Die oorsprong van dissiplinêre probleme kan moontlik toegeskryf word aan die afwesigheid van 'n waardestelsel as 'n deel van ' $n$ besondere lewens- en wêreldbeskouing, want daarsonder bly die hantering van dissiplinêre probleme slegs simptomaties.

\section{Introduction}

When looking at reports on the lack of discipline in South African schools, the absence of consideration for one another in society, the high crime rate and incidences of violence, one realises that currently a lack of values conducive to a healthy society and a welldisciplined school community is evident. In a study undertaken by De Wet (2003:36-44) it transpired that crime in schools was indeed a problem. The lack of discipline as indicated by the behaviour of both learners and educators seems to be the primary cause of the erosion of a learning and educational culture in South African schools. The decline of discipline is not unique to South Africa, however. It is a world-wide phenomenon (Steyn et al., 2003:225). The problems underlying the moral decay and lack of discipline are not only problems specific to South Africa, but also occur in other countries such as the United States of America (Antes \& Nardini, 1994:215-216). Constructive discipline, which includes self-discipline and the acceptance of discipline, is widely regarded as the most important element of a positive learning culture (see De Beer, 1992:15). Therefore, what is necessary in schools is not new policy, more programmes or better projects, but virtuous people who live according to a specific value system. What leads to a lack of discipline or lies at the root of a lack of discipline, can possibly be ascribed to the absence of a value system grounded in a specific lifeview perspective. We should, therefore, perhaps rather speak of a value or virtue crisis in schools than of a discipline crisis.

Long hours are spent on incentives to raise the level of discipline and good behaviour in schools. Many of these attempts may only be the treatment of symptoms since the underlying issue of all disciplinary problems may be a lack of a sound value system. In the case of Christians, a sound value system implies a life and worldview grounded on Biblically-based principles. Unfortunately, at this point in time, the instilling and developing of discipline as a 
value does not seem to receive prioirity; the focus seems to be on the development of democratic values for nation-building. It is not necessarily wrong to prioritise nation-building values, but it is unacceptable not to stress disciplined behaviour as well. The rights of individuals are regarded as important in nation-building values that are expounded in official documents and policymaking. Attention to the inculcation of values such as equity, tolerance, multilingualism, openness, accountability and social honour (James, $2000: 1$ ) is not necessarily a problem; the problem is rather that these values are currently over-emphasised.

Two issues arise in discussions concerning discipline. The first pertains to values such as respect, honesty, responsibility and selfdiscipline that are not emphasised sufficiently and therefore can have little impact on schools. The second issue pertains to those values that presently should be regarded as important for South Africa. The ideals of OBE (Outcomes-Based Education), featuring notions of child-centredness and strategies such as group work, will not succeed if a lack of discipline, including self-discipline, exists. The reasons why the South African society has not succeeded in eradicating the problem of a lack of self-discipline include the overemphasis of individual rights, the negligence of personal responsibility, the lack of a fully-fledged public value system, failure by learners to be self-disciplined, failure of the system to guide learners to think and judge for themselves, and the absence of selfdisciplined role-models. By discussing the relation between values and discipline, we aim to emphasise the role that values can play in restoring order and discipline in especially our schools, but also in society. The return of order, discipline and values is significant in the context of a reformational view of the learner, education, values and discipline.

\section{Principles, values and education}

What is the origin of values? The answer to this question will explain the role that values play in the life of human beings. Values are, in the first place, the result of the application of a person's principles which he or she obtains from his/her worldview grounded in his/her religion. According to Fowler et al. (1990:52): “ ... educational values are grounded in life values developed in the context of a world view at the heart of which is a religious commitment of one kind or another". Although values and principles are closely related, they are not the same. Both are human related and give direction to man's existence on earth, but "principles are deep fundamental truths that have universal application. ... Principles are not values. A 
gang of thieves can share values, but they are in violation of the fundamental principles", according to Covey (1992:35). From a Biblically-based perspective, principles are the primary source and acting in accordance with principles people obtain or decide on their values.

To define the concept values and other related concepts such as norms and principles is no easy task and has been attempted by many academics and educators. Joubert (1986:2) sees the concept values as an important point of departure for a discussion of norms, order and desirability in the society. A norm is a way of measuring a criterion for desired behaviour (Van Rensburg \& Landman, 1992: 413). Values form the basis for the acceptance or rejection of norms.

Each person's way of thinking and acting is controlled by his/her values. A definition of values that is often quoted in relevant subjectrelated literature, even though the source is rather old, is that of Kluckhorn (1954:395). According to him, a value is an opinion or view, explicit or implicit, characteristic of an individual or a group, to which preference is given; in other words, a value implies opinions or views that are enticing, desirable, preferable and influence the choice of possible actions, intentions and end-behaviour. Plunkett (1990:9) deems values to be relatively stable choices or preferences about how to be or to behave and, in relation to education, concern for what education is considered to achieve. Values are directive when an individual has to make choices. In every choice, a certain group of values will influence his/her decision, for example, to be obedient to the instructions of the educator in the classroom. Values that will play a role in this decision can be self-value, authority value, social value and moral value. Halstead and Taylor (2000:169) describe values as "... the fundamental convictions which act as general guidelines to behaviour, the standards by which particular actions are to be good or desirable". For the Christian, values are determined by a life and worldview grounded in the Bible and this view will be the point of departure in every decision and action.

According to Van der Walt $(1999: 7,8)$ the Bible gives a clear explanation of the origin of values. God created heaven and earth, and therefore the whole creation is a reality. God rules creation through the laws of creation; these laws are valid and binding for all created beings. A distinction exists between natural things that do not have a choice but to obey the laws of creation, and the human beings who should obey these laws because laws outline the basic principles for man's existence on earth. A person allocates a specific value to the laws that he/she is supposed to obey. Man is not born with values, 
but only with the ability to allocate value to things in creation. The totality of the ways in which human beings value things in creation develops into a life and worldview. In other words, the realisation of values is the manifestation of a person's life and worldview in reality. Values are thus "... the standards of our actions and the attitudes of our hearts and minds that shape who we are, how we live, and how we treat other people" (Eyre \& Eyre, 1993:15). According to Bloom (1987:201) "authentic values are those by which a life can be lived, which can form a people that produces great deeds and thoughts".

Values and education are inseparable. Since ancient times the concept education has been defined to be much more than the mere transferring of knowledge. Education can briefly be described as the raising of an immature child towards a higher level of maturity. Education also implies the leading and direction given by the utilisation of certain norms and values grounded in the Bible so that the child can increasingly develop a mature view of life (Van der Walt, 1983:19). Values have, therefore, to be interpreted from the vantage point of a Biblical worldview and cannot be separated from education, because to educate from a Biblically-based perspective is to guide a child towards God.

The teaching of values cannot be separated from education, and education cannot be separated from values. Education at home or at school will always take place, if not in a formal way, then in an informal way or in accordance with the so-called hidden curriculum (Smith \& Montgomery, 1997:83). The transferring and teaching of values have been key functions of education throughout the ages. Hagerty (1995:77) concurs with this statement by saying that the goals of education are to develop knowledge and character. There can never be enough people to guard society from ill-disciplined individuals and, therefore, one of the main aims of education is to develop character, and to form people with healthy values.

\section{The relationship between values and discipline}

According to Van Rensburg and Landman (1992:326) pedagogic discipline implies the child's voluntary acceptance of the influence and teaching of the normed adult educator, and the child's personal appropriation of the knowledge, dispositions and ideals of the educator. In a narrower sense, pedagogic discipline denotes order, governance and the keeping of order so that the activity or work will not only continue smoothly but will also show progress in order to reach the desired aim. In a broader sense, discipline connotes not only external discipline, but also a personal or inner discipline 
prompted by the inner acceptance of being obedient to rules and regulations.

From a Biblical perspective, God has set boundaries and the person endowed with authority (in the classroom this will be the educator) must remain within these boundaries. The educator is a called being with the authority given to him/her by God and who has the duty to use that authority responsibly and with respect (Van der Walt, 1983:74-75). Learners on the other hand, have the responsibility to be obedient towards the order and structure in the classroom. The over-emphasis of human rights (the self-value) leads to neglect of the values of order and discipline (i.e. of obedience towards rules and regulations of other people rather than of the self). As a result, learners often do things that suit themselves; they do not want to be prescribed by an adult or educator, and reject the discipline of the educator, parent or community.

The problem in South Africa is not that we have a new dispensation based on a new Constitution, but rather that there is a problem with understanding the concepts that are often applied. A greater emphasis on respect and responsibility in a new democracy does exist, but it is not clear whether all people understand the responsibilities of having basic human rights. If we wish to actualise the moral vision of the Constitution, that is a future founded on the recognition of human rights, democracy, peaceful co-existence and the development of opportunities for all South Africans, the vision will have to be interpreted and empowered by corresponding basic principles (De Klerk, 1998:20). From a reformational perspective those values amount to the realisation of a worldview based on Biblical principles.

Durkheim (1973:148) emphasises the strong link existing between discipline and values. He regards classroom discipline as the very extension of the morality in the class: "Discipline is not a simple device for securing superficial peace in the classroom; it is the morality of the classroom as a small society." The ultimate goal of discipline is self-discipline - "... the kind of self-control that underlies voluntary compliance with just rules and laws, that is the mark of mature character, and that a civilized society expects of its citizens" (Hagerty, 1995:86). According to Hagerty (1995:70) "values represent the emotional rules by which a society ... organizes and disciplines itself. And values are the precious reminder that individuals obey to bring order and meaning into their personal and social lives". In view of these definitions, the importance of values- 
education as the foundation of discipline cannot be emphasised enough.

It is clear that discipline involves much more than the good organisation or management of the classroom and the school. It also includes an inner or personal discipline in both teachers and learners. The three concepts, namely education, values and discipline, have to be intrinsically bound together if there is to be any true education in the lives of children.

The moral crisis in schools boils down to learners who do not respect one another, their teachers, or property. The absence of a work ethics in both educators and learners, dishonesty, the absence of responsibility on all levels coincides with increasing selfcentredness; growing ethical illiteracy, vandalism and the increase of violence also add to this moral crisis. The spirit of poor discipline in schools does not only manifest in ill-disciplined learners, but is also exhibited by undisciplined educators who are not serious about and committed to their task and calling. There are many reports of educators abusing their authority and committing serious crimes (De Wet, 2003:39). Together with this seeming unmotivatedness of some educators, the levels of crime - even in schools - are proof of a sick society. One of the results of this culture of crime and violence in schools is the conclusion that justice will not prevail, and this in turn leads to a spirit of despair in the South African educational situation. All of these conditions contribute to poor discipline in our society as well as in our schools, and also to the disintegration of values such as honesty, integrity, tolerance, work diligence, sympathy, justice and respect (De Wet, 2003:38).

In a democracy the man in the street is responsible for ensuring a free and just society. People at grass roots level should therefore understand and be committed to the moral foundations of democracy, e.g. respect for the rights of the individual, concern for the common good, regard for the law and a willingness to assume the responsibilities of democratic citizenship. The instilling of healthy values by means of value-education is therefore essential for the success of a democracy. The concept healthy values has a pertinent meaning in a Biblically-based context.

The concept of democratic values does not mean that there should be no guidelines on how to behave, and that everyone can do as he or she pleases in such a "democratic" dispensation. In a democratic classroom, learners should have freedom within the boundaries set by the educator. These boundaries should neither be too narrow nor 
too wide and should give learners a degree of freedom of choice. This freedom of choice should be just enough to enable learners to apply it responsibly.

The teacher's job is to guide the learning process by providing clear limits, acceptable choices, and instructive consequences that hold children accountable for their actions. No threats or detective work. No lecturing or cajoling. No flip-flopping back and forth. And no power struggles. Children are simply provided with the information they need to make acceptable choices about their behaviour, then allowed to experience the consequences of those choices (Mackenzie, 1996:47).

This could be the current problem in South Africa, namely that the consequences of ill-disciplined behaviour are not brought home to the transgressors. Learners should learn that they have freedom of choice, but not freedom from the consequences of their choices.

All the above-mentioned statements give evidence to the tension that exits between different opinions about how the lack of discipline should be dealt with in South African schools. To re-instate something like corporal punishment is obviously not the solution to the problem, especially in view of the current emphasis on human rights. One of the problems seems to be that the maintaining of strict discipline is associated with the previous dispensation. On the other hand, the success of OBE (Outcomes-Based Education) has been jeopardised in the process, because an obvious lack of efficient structure and discipline exists in schools. All the ideals of childcentredness and strategies such as group work will come to nothing if there is no discipline in the classroom. We have to look for solutions in which discipline (in the sense of followership) is valued as a priority (cf. 4.4 of the introductory article to this volume entitled "'n Beginselgrondslag vir gesag, vryheid, orde en dissipline in die onderwysopset van die 21 ste eeu").

"Encourage self-discipline through cooperative interaction between persons in the learning environment. There should be role modelling of the discipline code by faculty and staff and an emphasis on positive feedback and cooperation", say Antes and Nardini (1994: 218.) Their opinion underscores the importance of the development of self-discipline in learners as well as the very important role the educator has to play in the development thereof by setting a positive example.

"It is often assumed that all that is needed to replace authoritarian approaches to conveying values, is to teach children to think for 
themselves. Reason will safely show the way to a civilised society. But is this so?" (Ashton \& Watson, 1998:183.) Unfortunately, it is not acceptable to leave a child to decide for himself/herself in every instance. The immature child needs guidance to obtain healthy values. It is desirable that children learn to think for themselves, but they should be able to do that in accordance with a Biblically-based life and worldview. This life and worldview can guide a child to the acceptance of worth-while values.

The values that play a role in the establishment and maintaining of discipline in the classroom include the following:

- In the first place, the value or relationship will play a role in discipline, because of indicators such as the acceptance of one another, equivalence and respect.

- The next value that has relevance is the value of morality, with indicators such as right/wrong, integrity, honesty, choices of conscience, good behaviour, etc.

- Juridical values will influence the view of man on discipline with indicators such as justice and equity, obedience, etc.

- A very important value for the issue of discipline is the value of self with indicators such as self-discipline and self-respect.

- Another value basic to promoting discipline is the value of authority with indicators such as power, personal authority and independence (Bagarette, 1995:46-52). These are the paramount values that need attention for influencing and improving the situation in the classroom, although the other values are also important.

Democracy sets very high demands on the moral fabric of people; democracy in our country will, however, not succeed if the people are not able to discipline themselves. OBE (Outcomes-based Education) will not succeed either, because it presupposes selfactivity and self-discipline. What is lacking in our schools is what Hagerty (1995:86) calls moral discipline which "seeks to develop students' reasoned respect for rules, the rights of others, and the teacher's legitimate authority; students' sense of responsibility for their own behaviour; and their responsibility to the moral community of the classroom".

\section{The instilling of values}

The next issue after clarifying the origin of values is the question how values are taught or instilled, and who should be responsible for 
this facet of education. It is agreed that parents, as the primary educators, are the first or primary sources of values for children. They have the responsibility to educate their offspring in all the values, as Bagarette (1997) classifies them, in order to guide wellbalanced individuals to maturity. Unfortunately parents often fail to do so. Research already undertaken indicates that our present society is a broken one as a result of the devastating presence of sin in creation. Children return to empty homes after school (Codrington, 2000:31); there is no role-model to help children with issues that they have experienced during the day and also no authority figure to discipline them if necessary. This situation leads to poorly disciplined children/learners who are apathetic towards authority (Codrington, 2000:31).

Value education is the product of not only the interaction between learner and teacher/educator, but of many "significant others" inside and outside the school. Society plays a central role in the development of moral and other values and it is from society that children absorb most of their values and attitudes. There are also other sources of values-education outside the school, of which the media is an important one. The media, especially televisioncharacters and actors, are becoming the youth's role models. It is via the media that the youth encounter the examples of ill-disciplined people whom they perceive to be role models to look up to (Codrington, 2000:32, 34-35).

The school, and more specifically the educator, are faced with the very important task of instilling values in learners. The role of the educator as moral agent is of utmost importance. Because ethical issues are complex and multi-dimensional, values-education will not be a simple one-dimensional issue. It involves reflection, decisionmaking, purposeful conduct, the moulding of good habits over time and the building of character. The morality of learners is the product of affective or emotive, conative and social powers that lead to a growing moral consciousness (De Klerk, 2003:48). According to Hersh et al. (1980:2) morality is not a choice between good motives, right reason or resolute action; morality comprises all three together.

For more clarity on different models or approaches of values or moral education, five models or approaches are discussed briefly. (The concept values education is used because some of the models of the past referred to moral education rather than to valueseducation). The objective is not to give a comprehensive discussion, but only to outline the different approaches to values or moral education. They cannot be exhaustively evaluated. 


\subsection{The consideration-model}

The first is the consideration-model of McPail et al. (1975). The aim of moral education is the development of mature social judgement, behaviour and moral maturity (McPail et al., 1975:2). Learners should learn to consider other people and help others in need through the example of the educator.

Behaviour and attitudes are 'contagious', in a psychological sense and there is much truth in the maxim that morals are caught, not taught. But an example is a form of education, perhaps its highest form (McPail et al., 1975:3).

The viewpoint of McPail et al. is connected to the perspective of the ethics of virtue where moral shaping takes place within the context of community. This approach is in accordance with the instruction in Scripture to consider other people. Christians are cautioned as follows: "Do unto others as you would have them do unto you". The harshness of the broken reality after the fall of man is seen in the fact that exactly the opposite tends to occur. In a study by the Medical Research Council regarding the rape of women, it became apparent that most women have been raped between the ages of 10 and 14 years and that in $37.7 \%$ of the cases the culprits were educators (Anon., 2001:3).

\subsection{Stages of moral development}

The second model is Kohlberg's (1978) stages of moral development. The relationship between "values" and "morals" is often explained by means of the theory of Kohlberg (1978), who defined the levels and stages of moral development and the ability of moral reasoning in the life of the man in the street.

- The first level of morality consists of obeying laws to avoid punishment and gain reward (the level of pre-conventional moral reasoning).

- The second level of morality consists of doing one's duty out of a sense of conscience and group identity (conventional moral reasoning).

- The third and final level of morality consists of a conscious choice of values, based upon one's perception of who one is and what life is about (the post-conventional moral reasoning) (Woolfolk, 1998:81-82).

The task of the educator is to be a facilitator of the learner's cognitive development by creating opportunities for the learner to 
reflect on moral dilemmas. Kohlberg's idea was to develop a programme for moral education where the educator should only be a neutral facilitator, but he later changed his view by saying "... my notion was mistaken ... the educator must be a socialiser, teaching value content and behaviour, and not only a Socratic or Rogerian process-facilitator of development" (Kohlberg, 1978:14). From a Christian perspective, the most important criticism against Kohlberg is that the educator, according to Kohlberg's original stance, should be a neutral facilitator who assists learners to reflect on moral dilemmas in an ever developing way. A Christian educator cannot educate neutrally, because in the first place the learner is a child of God who, because of the fall of man, leans towards wrong-doing. The educator's task requires much more than mere cognitive argumentation; he/she has to educate and exemplify the values from Scripture. Kohlberg's approach also follows the assumption that values such as honesty, integrity, regard for life, and respect, already form part of the learner's equipment, and that a distinction should only be made among the different values. The assumption is unfortunately often not true of learners in South African schools. This approach furthermore capitalises on a Western luxury, in the sense that is only possible because it can live off the deposited social capital from the Christian era.

\subsection{The social-action model}

The third is the social-action model of Newman et al. (1977). According to this model, education should lead to responsible citizenship and environmental awareness. The objective of this model is to empower learners to influence issues of common interest and policy-making. According to Newman et al. (1977:4) learners should learn that a feeling of environment-competence is a part of moral responsibility. The model has already played a role in the restoration of human dignity in South Africa and can still contribute to the changing of society into a more humane one. Scripture is very clear about the fact that Christians have a responsibility to be involved and to let positive changes take place, not only in broken communities and lives, but also with regard to the surrounding creation.

\subsection{Value clarification}

The fourth model is value clarification by means of which learners are encouraged to choose their own values without any interference from the educator. According to this model the individual is the only source for the determining of values and there should be no other 
influence (Raths et al., 1978:8). According to Raths et al. (1978:9) "there is an assumption in our value theory and the teaching strategies that grow from it, that humans can arrive at values by an intelligent process of choosing, prizing and behaving". Because this view represents a neutral value approach, the educator does not need to teach the learner values or set an example to emulate. As neutral facilitator he/she should only help the learner to choose his/her own values and act accordingly. The point of departure of the humanistic movement, on which the value-clarification model is based, is irreconcilable with Christian convictions - for several reasons. To the Christian, man with his emotions and desires is not the final criterion of good and bad, and right and wrong is not merely a matter of personal taste. The egocentric individualism that is a consequence of this approach should be subordinated to the interpretation of the will of God. The instruction in Proverbs 22:6 "Train a child in the way he should go, and when he is old he will not turn from it" is in direct contrast with the notion of a neutral facilitator that is a basic tenet of both Kohlberg's first position and of the valueclarification model. In terms of the Christian framework, education cannot be neutral. Education is always norm-orientated and is about the inculcation of Christian norms and values. The value-clarification model with its foundation of moral relativism encourages selfishness and is not in accordance with a Christian life-view.

\subsection{Character education}

The last model to be discussed is character education, which is an attempt by schools, families and communities to help young people to understand core values, to care for them and to act according to them (Lickona, 1996:93). Lickona (1996:95) postulates that

... character education asserts that the validity of these values and their power to hold us accountable, derive from the fact that these values affirm our human dignity; they promote the development and welfare of the individual person; they serve the common good; they meet the classical ethical test of reversibility; and they define our rights and responsibilities in a democratic society. The school makes it clear that these basic human values are affirmed by civilised people and transcend religious and cultural differences. They express our common humanity.

Character education is a comprehensive approach and the educator acts as moral mentor who should instill values by means of the curriculum and other school rituals and also exercise discipline with the support of the parents. This model can thus be used to instill 
Biblical values in schools. The danger that it can degenerate into indoctrination can, however, be part of this approach.

The above-mentioned models are not the only ones that can be applied to obtain values-education. In order to avoid the two dilemmas of values-education, namely indoctrination and relativism, the above-mentioned approaches need to be combined. Whether the emphasis will be stronger on child-centred values-clarification or on the instilling of values through character education, will depend on the child's level of maturity. The more mature the child the more he/she will be able to think and reason independently, but then the basic principles should already have been established.

\section{The role of the school in values-education}

According to the Manifesto on Values, Education and Democracy (DoE 2001; iv-v), the ten values which are of paramount importance in South African schools are the following: democracy, social justice and equity, equality, non-racism and non-sexism, human dignity (ubuntu), an open society, accountability, the rule of law, respect and reconciliation. This list of values sounds very promising on paper, but to bring about real change in South African schools the following should also figure prominently:

- An understanding of these principles;

- a willingness to live accordingly,

- a civilised degree of moral literacy, accompanied by

- a culture of learning and teaching.

The above-mentioned ten values are the values important to the Government. They are the values on which educators should focus according to the Department of Education. The values concern themselves with all the children in our multi-cultural society and the aim of these values is nation-building in the context of this diversity.

Since Kader Asmal's appointment as Minister of Education, it has become quite evident that he has been entrusted with the task of "cleaning up" the South African education system so that President Mbeki's dream of an African Renaissance can become a reality. In February 2000, the Minister of Education requested that a work group be formed to work on values in education, in particular values relating to equity, tolerance, multi-lingualism, openness, accountability and social respect in schools. In the work group's report it is stated that they also consider the values mentioned previously as 
important for young people and would encourage the schooling system to actively promote them (James, 2000:1-12). The work group further stated three more reasons for the promotion of the above-mentioned values: Firstly, to develop the intellectual abilities and critical faculties of learners; secondly, to include the rich variety and diversity in culture, language and mores of our citizenry; thirdly, to equip learners with the skills to deal with the many challenges of the circle of life (James, 2000:1).

The following citation is proof of the intention to focus on the changes that should take place in classrooms as well as of the fact that the Government is serious about changing the wrongs of the past. "The value of 'accountability' focus ... on shifting schools from places of authoritarian discipline to those of orderly child-centred learning, and highlight ... the importance of teachers as role-models ..." (Asmal, 2001:8.) In research on values undertaken on behalf of the Department of Education in South African schools in, educators responded by saying that they experience a "... need for old-style authoritarian discipline and control in the classroom" (Asmal, 2001:61). Educators want a structured and orderly environment in the classroom as well as in the school. The researchers further concluded that "... until educators experience the concept of 'childcentred' learning as a mechanism to gain (rather than to lose) respect and discipline in their classrooms, the tension between repressive and rights-centred interpretations of values is likely to continue" (Asmal, 2001:61). Tension exists between the "authoritarian discipline" of the dispensation where the child had little say in the learning process and in the classroom as well, and the new child-centred approach. There is tension between the concepts of rights and responsibilities because having rights in a society also means that the individual has some responsibilities. To act responsibly implies that individuals must possess self-discipline, for without self-discipline and discipline all the wonderful ideas and ideals for this young democracy will come to nothing.

In his address at the Saamtrek on 'Values, education and democracy in the 21st century" Mandela (2001:55) said that "... the approach to nation-building was not only reflected in the conduct of individuals and national leadership, but also in the institutions we created. The Constitution is the highest expression of the values of nation-building ...". He furthermore stressed the importance of the example adults must set in the acquisition of values. "Parents or educators or politicians or priests who say one thing and do another send mixed messages to those in their charge who then learn not to trust them" (Mandela, 2001:56). 
The Government with its value system focused on nation-building and redress is imprinting it on education, but the problem is that these values are socially constructed by politicians and anchored in a human rights-philosophy.

The question of how to root values in firmer soil has been addressed in a different way through the language of human rights. This is now one of the most favoured means of expressing agreed moral imperatives, and has the great advantage that the language is international and entails no explicit reference to belief (Habgood, 1990:109).

This approach, however, has certain implicit weaknesses, because it is "dependent on a political process" and "historically (based) on an implicit morality, itself derived from religious beliefs, despite the fact that the early protagonists of human rights often had to fight for them against religious authorities" (Habgood, 1990:110). He further states that "when we ask what it is which undergirds such assertions as the equality of all people or the dignity of the individual, it is difficult to avoid tracing the connections back to traditional Protestants' ideas about a personal relationship with God" (Habgood, 1990:110). He thus grounds democratic values also in a Christian life view. A person's values in life are the realisation of his/her worldview.

The focus on values prescribed by the Department of Education centres in the building of a democratic society. However, a democratic society requires disciplined citizens. It is, therefore, important that our youth will be self-disciplined individuals with a healthy set of values grounded in their worldview, which will guide them through life. From a reformational view of values and education, the values contained in the Manifesto and in other official documents have to be re-interpreted in the light of Biblically-based perspectives. For such values to have any significant effect in society, they also have to be re-interpreted for the purpose of transforming them into guiding lights and norms for education. Education in this sense will have greater meaning and impact than applications of the "content-lacking" values currently encapsulated in official documentation. Values acquire meaning only when filled with life-view contents.

\section{Conclusion}

The educational situation is a normative one, in the sense that it is supported and directed by norms and values, preferably - in our opinion - from a reformational (Biblically-based) perspective. The absence of discipline in schools, self-discipline among learners and 
educators, as well as the overemphasis of individual rights, are causing negativity in schools because good quality education cannot take place and the ideals of OBE cannot be realised. The absence of internalised values based on a specific life-view perspective (for example, one based on Biblical principles) can be seen as one of the root causes of discipline problems in South African schools. Any attempt, therefore, to address discipline problems will have to start with the instilling of values based on specific life-view perspectives in schools. The government's emphasis on nation building values also in schools - is in itself not contradictory to values embedded in the fibre of the Bible. This emphasis is, however, not sufficient to ensure true education in the most profound sense of the word. Not only nation-building, but also character-building should be emphasized. Christian educators regard this is as their duty and tend to relate character-building and discipline directly to perspectives implicit in the Bible. A person's existence on earth should be in accordance with the principles of the Bible, which is the guide for his or her life and also for the choices he or she will make. Society has to realise that it is not only the work and responsibility of the school to instil values but also of the parents and other stakeholders such as the church and the media. It is not only the task of the school to help young people to make wise choices and to act with self-discipline, but also of the broader society.

\section{Bibliography}

ANON. 2001. Onderwysers skuldig aan verkragting. Die Burger: 11, Maart. 3.

ANTES, R.L. \& NARDINI, M.L. 1994. Another view of school reform values and ethics. Counselling \& Values, 38(3):215-223.

ASHTON, E. \& WATSON, B. 1998. Values education: a fresh look at procedural neutrality. Educational Studies (Carfax Publishing), 24(2):183-194.

ASMAL, K. 2001. Pride vs. arrogance: The new patriotism. Saamtrek: Values, education and democracy in the 21st Century. Conference Report. National Conference. Kirstenbosch, 22-24 February.

BAGARETTE, N. 1995. Die taksering van voornemende skoolhoofde se waarde-oriëntasies deur bestuursliggame. Bloemfontein : Universiteit van die Oranje-Vrystaat. (Ph.D.-proefskrif.)

BLOOM, A. 1987. Closing of the American mind. London: Penguin Books.

CODRINGTON, G.T. 2000. Multi-generational ministries in the context of a local church. Pretoria : University of South Africa. (Master of Diaconiologiadissertation.)

COVEY, S.R. 1992. The seven habits of highly effective people. London : Simon \& Schuster.

DE BEER, S. 1992. Back to learning. SACHED. The National Education Conference. Johannesburg : Ravan.

DE KLERK, J. 1998. A reappraisal of character education in a progressive postmodernist era. South African Journal of Education, 18(1):19-24. 
DE KLERK, J. 2003. Die kompleksiteit van morele opvoeding in Suid-Afrikaanse skole. Nederduitse Gereformeerde Teologiese Tydskrif, 44(1, 2):47-60.

DE WET, C. 2003. 'n Media-analise oor misdaad in die Suid-Afrikaanse onderwys. South African Journal of Education, 23(1):36-44.

Department of Education (DoE). 2001. Manifesto on Values, Education and Democracy 2001. Cape Argus Teach Fund for the Department of Education.

DoE see Department of Education

DURKHEIM, E. 1973. Moral education. New York : Free Press.

EYRE, L. \& EYRE, R. 1993. Teaching our children values. New York : Simon \& Schuster.

FOWLER, S., VAN BRUMMELEN, H.W. \& VAN DYK, J. 1990. Christian schooling education for freedom. Potchefstroom : Potchefstroom University for $\mathrm{CHE}$.

HAGERTY, R. 1995. The crisis of confidence in American education: a blueprint for fixing what is wrong and restoring America's confidence in the public schools. Springfield, Illinois : Thomas.

HABGOOD, J. 1990. Are moral values enough? British Journal of Educational Studies, 38:106-115.

HALSTEAD, J. \& TAYLOR, M. 2000. Learning and teaching about values: A review of recent research. Cambridge Journal of Education, 30(2):169-223, Jun.

HERSH, R.H., MILLER, J.P. \& FIELDING, G.D. 1980. Models of moral education. New York : Education Longman.

JAMES, W., ed. 2000. Values, education and democracy - Report of the Working Group on Values in Education. Pretoria : Department of Education.

JOUBERT, D. 1986. Waardes: navorsing, metodologie en teorie. RGNondersoek en navorsingsmetodologie. Navorsingsverslaereeks: 2. Pretoria: Raad vir Geesteswetenskaplike Navorsing.

KLUCKHORN, C. 1954. Values and value orientations in the theory of action. (In Parsons, T. \& Shils, E.A.. ed. Toward a general theory of action. Cambridge : Harvard University Press. p. 388-433.)

KOHLBERG, L. 1978. Moral education repraised. The Humanist: 12-18, Nov./Dec.

LICKONA, T. 1996. Eleven principles of effective character education. Journal of Moral Education, 25(1):93-95.

MACKENZIE, R.J. 1996. Setting limits in the classroom. Rocklin : Prima.

MANDELA, N. 2001. Address at Saamtrek: Values, Education and Democracy in the 21st Century. Conference Report. National Conference. Kirstenbosch, 22-24 February.

MCPAIL, P.J.R., THOMAS, U. \& CHAPMAN, H. 1975. Learning to care. Niles : Argus Communications.

NEWMAN, F.M., BERTOCCI, T. \& LANDSNESS, R.M. 1977. Skills in citizen action - an English social studies program for secondary schools. Wisconsin : University of Wisconsin Publications.

PLUNKETT, D. 1990. Secular and spiritual values - grounds for hope in education. London : Routledge.

RATHS, L.E., HARMIN, M. \& SIMON, S. 1978. Values and teaching. Ohio : Merril. 
SMITH, A. \& MONTGOMERY, A. 1997. Values in education in Northern Ireland. Belfast : Northern Ireland Council for the Curriculum, Examinations and Assessment.

STEYN, S.C., WOLHUTER, I.J., OOSTHUIZEN, I.J. \& VAN DER WALT, J.L. 2003. 'n Internasionale perspektief op leerderdissipline in skole. South African Journal of Education, 23(3):225-232.

VAN DER WALT, B.J. 1999. Die oorsprong van ons waardekrisis en hoe ons weer duidelike, positiewe Christelike waardes kan terugvind. Potchefstroom : IRS. (Instituut vir Reformatoriese Studies, Studiestuk 381.)

VAN DER WALT, J.L. 1983. Oor opvoeding in 'n neutedop. Silverton : Promedia Publikasies.

VAN RENSBURG, C.J.J. \& LANDMAN, W.A. 1992. Fundamenteel-pedagogiese begripsverklaringe/Notes on fundamental-pedagogic concepts. Pretoria : N.G Kerkboekhandel.

WOOLFOLK, A. 1998. Educational psychology. Boston : Allyn \& Bacon.

\section{Key concepts:}

discipline

education

principles

values

\section{Kernbegrippe:}

beginsels

dissipline

opvoeding

waardes 
